\title{
Emerging Markers of Atherosclerosis Before and After Bariatric Surgery
}

\author{
Justyna Domienik-Karlowicz • Zuzanna Rymarczyk • \\ Olga Dzikowska-Diduch • Wojciech Lisik • \\ Andrzej Chmura • Urszula Demkow • Piotr Pruszczyk
}

Published online: 28 September 2014

(C) The Author(s) 2014. This article is published with open access at Springerlink.com

\begin{abstract}
Objective The objective of this study was to assess the emerging biochemical markers of arterial remodeling in patients with morbid obesity before and after surgical treatment and to compare the results to a control group.

Material and Methods The prospective study included 40 patients with BMI $47.73 \pm 6.18 \mathrm{~kg} / \mathrm{m}^{2}$, qualified for elective bariatric surgery and re-examined 6 months after the surgery. The control group consisted of non obese, age and sex matched 15 subjects. Following laboratory examinations were performed in all patients: basic laboratory examinations, MMP-2, MMP-9, adiponectin, PAI-1, CD40L, E-selectin.
\end{abstract}

J. Domienik-Karłowicz · Z. Rymarczyk • O. Dzikowska-Diduch •

P. Pruszczyk

Department of General Medicine and Cardiology, Medical

University of Warsaw, Lindley'a 5, 02-005 Warsaw, Poland

J. Domienik-Karłowicz

e-mail: jdomienik@tlen.pl

Z. Rymarczyk

e-mail: zrymarczyk@wp.pl

O. Dzikowska-Diduch

e-mail: ola.dzikowska@wp.pl

P. Pruszczyk

e-mail: piotr.pruszczyk@wum.edu.pl

W. Lisik $(\square) \cdot$ A. Chmura

Department of General Surgery and Transplantology, Medical

University of Warsaw, Nowogrodzka 59, 02-005 Warsaw, Poland

e-mail: wojciech.lisik@wum.edu.pl

A. Chmura

e-mail: andrzej.chmura@wum.edu.pl

\section{U. Demkow}

Department of Laboratory Medicine and Clinical Immunology of Developmental Age, Medical University of Warsaw, Marszałkowska 24, 00-576 Warsaw, Poland

e-mail: urszula.demkow@wum.edu.pl
Results Examination of patients $6 \mathrm{~m}$ after bariatric surgery revealed a $34.57 \pm 9.71$ reduction in excess body weight. Comparison of the study group at two time points revealed differences in adiponectin, MMP-2 and MMP-9 levels. Hypoadiponectinemia was observed in $35 \%$ patients 6 months after bariatric surgery compared to $90 \%$ patients before the surgery. In addition, a strong correlation was observed between body fat mass and adiponectin levels $(r=-0.504$, $p=0.055)$. Moderate correlations were demonstrated between E-selectin levels and BMI $(r=0.361 ; p=0.022)$, and metalloproteinase-9 levels $(r=0.326 ; p=0.040)$. In addition, strong relationship was demonstrated between MMP-2 and MMP-9 $(r=0.502 ; p=0.001)$, and moderate between MMP-2 and adiponectin levels $(r=0.449 ; p=0.003)$. MMP-9 levels were moderately correlated with HDL-cholesterol levels $(r=$ $0.316 ; p=0.046$ ).

Conclusions Assessment of laboratory markers of arterial remodeling and metabolism suggest their adverse changes in patients with morbid obesity. However, body mass reduction due to bariatric surgery decreases inflammatory status, improves biochemical markers of arterial remodeling as well as to beneficial changes in the metabolism.

Keywords Atheroslerosis $\cdot$ Bariatric sugery $\cdot$ Morbid obesity $\cdot$ Emerging markers $\cdot$ MMP

Obesity is an established risk factor for a number of cardiovascular disorders. The adipose tissue is a complex, metabolically active organ and a source of pro-inflammatory cytokines. Hormones produced by the adipose tissue play a key role in the energy balance and the metabolism of carbohydrates and lipids [1]. Due to the activity of pro-inflammatory cytokines, individuals with excess adipose tissue experience chronic inflammation which leads to progressive dysfunction in the endothelium, recruitment of further inflammatory cells, 
remodeling of the blood vessels [2-4] with the development of intermediate plaque. Activation of inflammatory cells producing cytokines and chemokines leads to the development of complex plaque [3].

Development of atherosclerosis involves activity of extracellular matrix metalloproteinases (MMP-2 and MMP-9), adiponectin, E-selectin, PAI-1, and CD40L. Extracellular matrix metalloproteinases are involved in remodeling of extracellular matrix and basal membranes. Disturbed equilibrium between MMPs and their inhibitors (tissue inhibitors of metalloproteinases, TIMPs) [4] and $\alpha$-2-macroglobulin leads to enhanced proteolysis and endothelial damage or to accumulation of matrix constituents [5]. MMPs were demonstrated to play an important role in the atherosclerotic process, modulation of adipogenesis, [6] remodeling of the walls of blood vessels and myocardium $[7,8]$.

Adiponectin is a polypeptide hormone, produced and secreted into blood only by adipose tissue cells [9]. According to many authors, production of adiponectin is, in contrast to other hormones originating from the adipose tissue, negatively correlated with the body weight, visceral fat, and BMI, [10] although not all studies have confirmed this hypothesis [11-14]. Abbasi et al. demonstrated that a small drop in body weight due to non-surgical methods does not significantly affect the adiponectin levels; [13] In clinical practice, hypoadiponectinemia is considered to be a predictor of type II diabetes, lipid disorders, arterial hypertension and nonalcoholic liver fatty liver disease. Schondorf et al. determined the reference adiponectin levels to be in the range of $7-12 \mathrm{mg} /$ L. Values lower than 7 suggest hypoadiponectinemia and are a strong indicator of complications within the cardiovascular system $[15,16]$.

The CD40 ligand (CD40L) belongs to the family of tumor necrosis factor (TNF alpha) cytokines. It is an element of the CD40/CD40L transmitter system. It should be highlighted that studies published to date suggest elevated SCD40L levels in type II diabetes, [17-19], metabolic syndrome, [17, 20]. Data on the relationship between CD40L levels and obesity and morbid obesity are ambiguous [21,22].

E-selectin, is a membrane protein from the selectin group. Data on the relationship between E-selectin levels and body weight/BMI are ambiguous. Palomo et al. demonstrated no difference between E-selectin levels in a group of metabolic syndrome patients and patients without metabolic syndrome [20]. Hanusch-Enserer et al., who conducted a study in a group of 32 patients with morbid obesity subjected to LAGB demonstrated that E-selectin levels were positively correlated with BMI both before and after the surgery [23].

Elevated plasminogen activator inhibitor-1 (PAI-1) levels, were observed in patients with obesity. It was suggested that bariatric surgeries lead to positive outcomes, as PAI-1 levels in patients after the surgery are lower than before the surgery [24].

\section{Objectives}

The objective of this study was to assess the emerging biochemical markers of arterial remodeling in patients with morbid obesity before and after gastric bypass surgery and to compare the results to a control group consisting of individuals with normal body weight.

\section{Methods}

The prospective study included 40 female patients with morbid obesity, BMI $47.73 \pm 6.18 \mathrm{~kg} / \mathrm{m}^{2}$, qualified for elective gastric bypass surgery and re-examined 6 months after the surgery. Patients with the history of myocardial infarction or with significant valvular heart disease, chronic renal disease $\left(\mathrm{GFR}<60 \mathrm{ml} / \mathrm{min} / 1,73 \mathrm{~m}^{2}\right)$, chronic hepatic insufficiency, or chronic obstructive pulmonary disease, smokers ( $>20$ cigarettes/day), and patients with obstructive sleep apnea (acute, AHI $\geq 30$ ) were excluded from the study.

The control group consisted of non obese, age and sex matched 15 subjects.. Anthropometric measurements and laboratory analyses were performed in all study subjects. Body weight, fat body mass and lean body mass values were determined using Tanita TBF-300 Body Composition Analyser based on electric bioimpedance measurements. Ideal body weight (IBW) was calculated according to the following formula: (age in $\mathrm{cm}-100$ )-10\%; excess body weight (EBW) was calculated according to the following formula: current body weight-ideal body weight; $\%$ excess weight loss $(\% \mathrm{EWL})$ was calculated according to the following formula: (body weight before surgery-body weight 6 months after surgery)/ excess body weight before surgery x 100 .

Following laboratory examinations were performed in all patients: complete blood counts, lipid profile, creatinine (mg/dL), hsCRP (mg/L), $\mathrm{HbA}_{1} \mathrm{C}(\%)$, serum glucose (mg/dl) and serum insulin $(\mu \mathrm{IU} / \mathrm{mL})$ by immunochromatography, MMP-2 - Ray Biotech ELISA kit, MMP-9 - Ray Biotech ELISA kit, adiponectin - Teco Medical ELISA kit, PAI-1 Biovendor ELISA kit, CD40L - GEN PROBE diaclone ELISA kit, E-selectin - GEN PROBE diaclone ELISA kit. The study protocol was approved on 31 March 2009 by the Local Bioethics Committee. 


\section{Statistical Analysis}

Quantitative variables were analyzed using standard descriptive statistic measures: means, standard deviations for normal distribution variables and medians and ranges for non-normal distribution variables. The hypothesis of variable distribution being consistent with normal distribution was tested for quantitative variables. To this end, Shapiro-Wilk's test and Q-Q plot test were used. When distribution of a particular variable was normal, the hypothesis of the means in two study groups being equal was examined using the Student's $t$-test. Wilcoxon's test for independent samples was used to compare two groups in case of parameters demonstrating deviations from normal distribution. The analysis of quantitative parameters of management involved the following dependent sample tests: Student's $t$-test for normal distribution variables and Wilcoxon's test for non-normal distribution variables. Correlations between quantitative variables involved Pearson's coefficient for normal distribution variables and Spearman's coefficient for non-normal distribution variables. The relationships between qualitative variables were studied in contingency tables using the chi-square test or Fisher's exact test when the expected values in table cells were not high enough (i.e. above 5). The analysis of changes in qualitative parameters during the treatment involved the McNemar's test for the symmetry of related samples. The level of statistical significance was established at $p<0.05$. Calculations were performed using the SAS 9.2 software.

\section{Results}

\section{Overall Clinical Characteristics of Morbid Obesity Patients}

A total of 40 patients with pathological obesity, aged $36.4 \pm$ 9.0 years were included into the study. All patients were reexamined approximately 6 month after the surgery Table 1

Table 1 Anthropometric parameters of patients qualified for bariatric surgery (OB1) and the control group (CG)

\begin{tabular}{lccl}
\hline & OB1 $(n=40)$ & CG $(n=15)$ & $\mathrm{p}$ \\
\hline Body weight $(\mathrm{kg})$ & $132.03 \pm 18.42$ & $60.73 \pm 5.12$ & $<0.0001$ \\
BMI $\left(\mathrm{kg} / \mathrm{m}^{2}\right)$ & $47.73 \pm 6.18$ & $21.61 \pm 1.41$ & $<0.0001$ \\
FAT $(\%)$ & $49.15 \pm 3.83$ & $25.13 \pm 4.88$ & $<0.0001$ \\
FFM $(\mathrm{kg})$ & $66.78 \pm 7.84$ & $45.37 \pm 3.7$ & $<0.0001$ \\
BSA M $\left(\mathrm{m}^{2}\right)$ & $2.47 \pm 0.20$ & $1.68 \pm 0.09$ & $<0.0001$ \\
EBW $(\mathrm{kg})$ & $72.34 \pm 16.75$ & & \\
\hline
\end{tabular}

presents the anthropometric parameters of patients qualified for the surgery and patients in the control group.

Arterial hypertension was diagnosed in 38 (95\%) patients. Initially $30(75 \%)$ patients received 2 or more hypotensive drugs (including ACE inhibitors and a diuretic); while $8(20 \%)$ patients received only one hypotensive drug (ACE inhibitor). Pre-diabetes was diagnosed in $11(27.5 \%)$ patients, including impaired fasting glucose in 6 patients $(15 \%)$ and impaired glucose tolerance in $7(17.5 \%)$ patients [25]. Both of these abnormalities were observed simultaneously in 2 patients $(5 \%)$. Patients diagnosed with type 2 diabetes were excluded from the study. Lipid metabolism disorders were observed in $22(55 \%)$ patients, while 8 $(20 \%)$ patients were diagnosed with obstructive sleep apnea of not more than moderate intensity.

Assessment of Blood Chemistry Parameters in Patients with Morbid Obesity

Table 2 presents the blood chemistry parameters observed in patients with morbid obesity

Comparison of Blood Chemistry Parameters in the Group of Patients with Morbid Obesity (OB1) and the Control Group (CG)

Table 3 presents comparison of blood chemistry parameters in the group of patients with morbid obesity and the control group

Assessment Pre- and Post-Surgery Anthropometric

Parameters in Patients with Morbid Obesity

Table 4 presents the comparison of anthropometric parameters in the study group before the bariatric surgery and 6 months after bariatric surgery.

Table 5 compares the study results comparing blood chemistry parameters in patients before bariatric surgery and 6 months after bariatric surgery.

In addition, a strong negative correlation was observed between body fat mass and adiponectin levels $(r=-0.504, p=0.055)$.

Moderate correlations were found between E-selectin levels and BMI $(r=0.361 ; p=0.022)$, MMP-9 levels $(r=0.326$; $p=0.040$ ). Mutual strong correlation was observed between metalloproteinases MMP-2 and MMP-9 ( $r=0.502$; $p=0.001$ ). In addition, ("strong" removed) moderate relationship was demonstrated between MMP-2 and adiponectin levels ( $r=0.449 ; p=0.003)$. On the other hand, MMP-9 levels were moderately correlated, as mentioned previously, with E- 
Table 2 Assessment of blood chemistry parameters in patients with morbid obesity

\begin{tabular}{lllll}
\hline & mean & \pm SD & median & range \\
\hline fasting glucose $(\mathrm{mg} / \mathrm{dL})$ & 90.4 & 10.19 & 89 & $67.0-124.0$ \\
fasting insulin $(\mu \mathrm{IU} / \mathrm{mL})$ & 17.68 & 11.29 & 14.07 & $5.45-56.33$ \\
HOMA-IR & 3.89 & 2.33 & 3.31 & $1.14-11.68$ \\
creatinine $(\mathrm{mg} / \mathrm{dL})$ & 0.76 & 0.16 & 0.7 & $0.5-1.3$ \\
total cholesterol $(\mathrm{mg} / \mathrm{dL})$ & 199.15 & 35.13 & 197.5 & $129.0-296.0$ \\
HDL-chol $(\mathrm{mg} / \mathrm{dL})$ & 52.55 & 10.97 & 50.5 & $36.0-86.0$ \\
LDL-chol $(\mathrm{mg} / \mathrm{dL})$ & 120.3 & 31.59 & 119.5 & $52.0-240.0$ \\
triglycerides $(\mathrm{mg} / \mathrm{dL})$ & 124.78 & 47.7 & 114 & $31.0-255.0$ \\
hsCRP $(\mathrm{mg} / \mathrm{L})$ & 10.19 & 6.92 & 8.8 & $1.9-32.02$ \\
HbA $\mathrm{C}(\%)$ & 5.8 & 0.89 & 5.65 & $5.2-6.6$ \\
CD40L $(\mathrm{ng} / \mathrm{mL})$ & 3.63 & 34.3 & 1.96 & $0.02-17.51$ \\
E-selectin $(\mathrm{ng} / \mathrm{mL})$ & 68.49 & 38.94 & 56.48 & $21.87-191.71$ \\
Adiponectin $(\mathrm{ng} / \mathrm{mL})$ & $4,976.34$ & $2,728.36$ & $4,345.94$ & $1,893.15-16,270.60$ \\
MMP-2 $(\mathrm{ng} / \mathrm{mL})$ & 70.15 & 74.11 & 46.19 & $11.23-419.06$ \\
MMP-9 $(\mathrm{ng} / \mathrm{mL})$ & 10,061 & $4,510.67$ & $8,546.49$ & $2,210.59-30,522.40$ \\
PAI $(\mathrm{pg} / \mathrm{mL})$ & 257,373 & 175,597 & 246,291 & $20,639.20-818,896$ \\
\hline
\end{tabular}

selectin levels $(r=0.326 ; p=0.040)$ as well as with HDLcholesterol levels $(r=0.316 ; p=0.046)$.

\section{Changes in Studied Parameters 6 Months After Bariatric Surgery}

Examination of patients 6 months after bariatric surgery revealed a $34.57 \pm 9.71 \mathrm{~kg}$ reduction in excess body weight. This change was accompanied by changes in laboratory parameters. Statistically significant changes and changes important for presentation of the results are presented in Tables 6 and 7 .

\section{Discussion}

The study assessed, in a non-invasive manner, emerging markers of atherosclerosis in patients with morbid obesity as compared to the control group with normal body weight, as well as the efficacy of gastric bypass surgery of obesity in normalization of these parameters. A total of 40 female patients with morbid obesity, meeting the qualification criteria for bariatric surgery, were qualified for the study [26]. Patients qualified for gastric bypass surgery were not different from the control group subjects in age while differing in BMI range for
Table 3 Comparison of blood chemistry parameters in the group of patients with morbid obesity and the control group

\begin{tabular}{llll}
\hline & OB1 (median, range) & CG (median, range) & $\mathrm{p}$ \\
\hline fasting glucose $(\mathrm{mg} / \mathrm{dL})$ & $89 ; 67-124$ & $90 ; 81-102$ & $\mathrm{NS}$ \\
fasting insulin $(\mu \mathrm{IU} / \mathrm{mL})$ & $14.07 ; 5.45-56.33$ & $6.81 ; 3.57-12.73$ & $<0.0001$ \\
HOMA-IR & $3.31 ; 1.14-11.68$ & $1.61 ; 0.78-3.02$ & $<0.0001$ \\
creatinine $(\mathrm{mg} / \mathrm{dL})$ & $0.7 ; 0.5-1.3$ & $0.8 ; 0.6-0.9$ & $\mathrm{NS}$ \\
total cholesterol $(\mathrm{mg} / \mathrm{dL})$ & $197.5 ; 129.0-296.0$ & $183 ; 129-233$ & $\mathrm{NS}$ \\
HDL-chol $(\mathrm{mg} / \mathrm{dL})$ & $50.5 ; 36.0-86.0$ & $69 ; 50-85$ & $<0.0001$ \\
LDL-chol $(\mathrm{mg} / \mathrm{dL})$ & $119.5 ; 52.0-240.0$ & $105 ; 52-145$ & 0.04 \\
triglycerides $(\mathrm{mg} / \mathrm{dL})$ & $114 ; 31.0-255.0$ & $51 ; 30-203$ & 0.001 \\
hsCRP $(\mathrm{mg} / \mathrm{L})$ & $8.8 ; 1.9-32.02$ & $0.60 ; 0.1-2.40$ & $\mathrm{NS}$ \\
HbA $\mathrm{C}(\%)$ & $5.65 ; 5.2-6.6$ & $5.60 ; 5.30-5.80$ & 0.001 \\
CD40L $(\mathrm{ng} / \mathrm{mL})$ & $1.96 ; 0.02-17.51$ & $0.56 ; 0.06-1.77$ & 0.0008 \\
E-selectin $(\mathrm{ng} / \mathrm{mL})$ & $56.48 ; 21.87-191.71$ & $54.41 ; 20.73-110.01$ & $\mathrm{NS}$ \\
Adiponectin $(\mathrm{ng} / \mathrm{mL})$ & $4,345.94 ; 1,893.15-16,270.60$ & $14,548.31 ; 5,392.68-26,099.29$ & $<0.0001$ \\
MMP-2 $(\mathrm{ng} / \mathrm{mL})$ & $46.19 ; 11.23-419.06$ & $28.05 ; 4.31-295.86$ & 0.03 \\
MMP-9 $(\mathrm{ng} / \mathrm{mL})$ & $8,546.49 ; 2,210.59-30,522.40$ & $7,304.87 ; 7,011.3-7,660.98$ & $<0.0001$ \\
PAI $(\mathrm{pg} / \mathrm{mL})$ & 246,$291 ; 20,639.20-818,896$ & $84,523.52 ; 33,281.73-181,843.26$ & 0.0003 \\
\hline
\end{tabular}


Table 4 Comparison of anthropometric parameters of patients 6 months after bariatric surgery $(n=40)$

\begin{tabular}{lccl}
\hline & OB1 & OB2 & $\mathrm{p}$ \\
\hline Body weight $(\mathrm{kg})$ & $132.03 \pm 18.42$ & $97.46 \pm 15.35$ & $<0.0001$ \\
BMI $\left(\mathrm{kg} / \mathrm{m}^{2}\right)$ & $47.73 \pm 6.18$ & $35.22 \pm 5.20$ & $<0.0001$ \\
FAT $(\%)$ & $49.15 \pm 3.83$ & $38.20 \pm 5.66$ & $<0.0001$ \\
FFM $(\mathrm{kg})$ & $66.78 \pm 7.84$ & $59.90 \pm 8.92$ & $<0.0001$ \\
BSA M (m $\left.{ }^{2}\right)$ & $2.46 \pm 0.19$ & $2.12 \pm 0.19$ & $<0.0001$ \\
EBW $(\mathrm{kg})$ & $72.34 \pm 16.75$ & $37.77 \pm 13.97$ & $<0.0001$ \\
\hline
\end{tabular}

obvious reasons. When comparing both groups, obese patients were found to exhibit higher fasting insulin levels and HOMA index values. In 19 patients with morbid obesity $(48,71 \%)$ fasting insulin levels exceeding $15 \mu \mathrm{IU} / \mathrm{mL}$ and suggesting hyperinsulinemia. At the same time, insulin resistance was diagnosed in $67 \%$ of morbidly obesity patients. No cases of hyperinsulinemia or insulin resistance were observed in the control group.

Also according to published reports mean triglyceride and LDL-cholesterol levels in the group of patients qualified for the surgery was higher than in the CG while the mean HDLcholesterol level was lower than in the CG. Medians of CD40L, adiponectin, MMP-2, MMP-9, and PAI-1 levels were higher in the group of morbid obesity patients as compared to the control group [27-29]. Hypoadinectinemia was diagnosed in $90 \%$ of patients qualified for the bariatric surgery and in $20 \%$ patients in the control group. This confirms previous observations suggesting high incidence of lipid metabolism disorders in obese individuals [30, 31].
Table 6 Correlations of changes in CD40L levels following bariatric surgery compared to baseline levels ( $\triangle$ E-CD40L) with changes in levels of selected biochemical parameters related to endothelial function

\begin{tabular}{lll}
\hline Parameter: $\Delta$ CD40L & $\mathrm{r}$ & $\mathrm{p}$ \\
\hline$\Delta$ total cholesterol & 0.937 & $<0.0001$ \\
$\Delta$ LDL-cholesterol & 0.854 & $<0.0001$ \\
$\Delta$ HDL-cholesterol & 0.477 & 0.0018 \\
$\Delta$ PAI & 0.431 & 0.0097 \\
$\Delta$ E-selectin & 0.4036 & 0.012 \\
\hline
\end{tabular}

After the surgery, following a 6-month follow-up period, a significant drop was observed in BMI, from $47.73 \pm 6.18 \mathrm{~kg}$ / $\mathrm{m}^{2}$ to $35.22 \pm 5.20 \mathrm{~kg} / \mathrm{m}^{2}(\mathrm{p}<0.0001)$, and EBW from $72.34 \pm$ $16.75 \mathrm{~kg}$ to $37.77 \pm 13.97 \mathrm{~kg}(\mathrm{p}<0.0001)$. Significant improvement in carbohydrate metabolic parameters was observed following the bariatric surgery. Elevated fasting blood glucose levels were observed in $6(15 \%)$ patients in the OB1 group; elevated fasting insulin levels of more than $15 \mu \mathrm{IU} / \mathrm{mL}$ were initially observed in 19 (48.7\%) of study group patients. A statistically insignificant drop was observed in the fasting blood glucose levels $(90.40 \pm 10.19 \mathrm{mg} / \mathrm{dL}$ vs. $85.35 \pm$ $9.50 \mathrm{mg} / \mathrm{dL}$; NS), highly significant $(\mathrm{p}<0.0001)$. drop in fasting insulin levels was observed; after the follow-up period of 6 months, fasting hyperinsulinemia was diagnosed only in $6(15 \%)$ patients. A decrease in insulin resistance as measured by the HOMA-IR index was also observed after the surgery. Our observations regarding the disturbed carbohydrate metabolism were in line with those in the available literature. Also Krebs et al., when studying a group of morbid obesity patients

Table 5 Comparison of blood chemistry parameters in patients before bariatric surgery and 6 months after bariatric surgery

\begin{tabular}{lccc}
\hline & OB1 (median, range) & OB2 (median, range) & $p$ \\
\hline fasting glucose $(\mathrm{mg} / \mathrm{dL})$ & $89 ; 67-124$ & $85.00 ; 66.00-109.00$ & 0.0139 \\
fasting insulin $(\mu \mathrm{IU} / \mathrm{mL})$ & $14.07 ; 5.45-56.33$ & $7.72 ; 1.67-108.00$ & $<0.0001$ \\
HOMA-IR & $3.31 ; 1.14-11.68$ & $1.76 ; 0.35-24.80$ & $<0.0001$ \\
creatinine $(\mathrm{mg} / \mathrm{dL})$ & $0.7 ; 0.5-1.3$ & $0.80 ; 0.5-1.0$ & $\mathrm{NS}$ \\
total cholesterol $(\mathrm{mg} / \mathrm{dL})$ & $197.5 ; 129.0-296.0$ & $191.00 ; 122.00-257.00$ & $<0.0001$ \\
HDL-chol $(\mathrm{mg} / \mathrm{dL})$ & $50.5 ; 36.0-86.0$ & $55.00 ; 38.00-80.00$ & $\mathrm{NS}$ \\
LDL-chol $(\mathrm{mg} / \mathrm{dL})$ & $119.5 ; 52.0-240.0$ & $112.50 ; 57.00-183.00$ & $\mathrm{NS}$ \\
triglycerides $(\mathrm{mg} / \mathrm{dL})$ & $114 ; 31.0-255.0$ & $88.50 ; 39.00-235.00$ & $<0.0001$ \\
hsCRP $(\mathrm{mg} / \mathrm{L})$ & $8.8 ; 1.9-32.02$ & $2.80 ; 0.4-25.50$ & $<0.0001$ \\
HbA $\mathrm{C}(\%)$ & $5.65 ; 5.2-6.6$ & $5.35 ; 4.70-6.10$ & $<0.0001$ \\
CD40L $(\mathrm{ng} / \mathrm{mL})$ & $1.96 ; 0.02-17.51$ & $2.00 ; 0.02-13.95$ & $\mathrm{NS}$ \\
E-selectin $(\mathrm{ng} / \mathrm{mL})$ & $56.48 ; 21.87-191.71$ & $54.05 ; 14.46-239.31$ \\
Adiponectin $(\mathrm{ng} / \mathrm{mL})$ & $4,345.94 ; 1,893.15-16,270.60$ & $8,972.87 ; 2,940.06-26,711.11$ & $\mathrm{NS}$ \\
MMP-2 $(\mathrm{ng} / \mathrm{mL})$ & $46.19 ; 11.23-419.06$ & $39.26 ; 8.90-141.47$ \\
MMP-9 $(\mathrm{ng} / \mathrm{mL})$ & $8,546.49 ; 2,210.59-30,522.40$ & $8,024.56 ; 2,210.59-46,160$ & 0.007 \\
PAI $(\mathrm{pg} / \mathrm{mL})$ & 246,$291 ; 20,639.20-818,896$ & $167,240.43 ; 19,175.87-622,270.64$ & 0.039 \\
\hline
\end{tabular}


Table 7 Correlations of changes in E-selectin levels following bariatric surgery compared to baseline levels ( $\Delta$ E-selectin) with changes in levels of selected biochemical parameters related to endothelial function

\begin{tabular}{llr}
\hline Parameter: $\Delta$ E-selectin & \multicolumn{1}{c}{$\mathrm{p}$} \\
\hline$\Delta$ total cholesterol & 0.348 & 0.0277 \\
$\Delta$ CD40L & 0.854 & $<0.0001$ \\
$\Delta$ MMP-9 & 0.302 & 0.0587 \\
\hline
\end{tabular}

without concomitant type II diabetes over a similar follow up period observed no significant changes in fasting blood glucose levels and a statistically significant drop in fasting insulin levels [32]. Increase in adiponectin levels correlated with the drop in body weight as the result of bariatric surgery was demonstrated in a number of studies. In our study material, hypoadiponectinemia, defined as adiponectin levels of $<7,000 \mathrm{ng} / \mathrm{mL}$ was observed in $90 \%$ of patients before the surgery and $35 \%$ of patients after the 6-month follow-up period. We believe that this change is worth a particular mention as, according to observations by Schondorf et al., adiponectin levels of less than $7,000 \mathrm{ng} / \mathrm{mL}$ are a predictor of very high risk of cardiovascular complications [15]. In this study, the change in adiponectin levels was strongly correlated with the change in hsCRP levels $(r=-0.519$, $p=0.0008)$. Therefore, what is very important, the inverse relationship between adiponectin and inflammation expressed as elevated hsCRP levels as described in numerous studies was confirmed [33].

A number of studies demonstrated that MMP-9 levels were higher in patients with obesity and in patients with metabolic syndrome as compared to patients with normal body weight $[27,28]$. Kosmala et al. observed that MMP9 levels were strictly correlated with BMI values in obese patients, [34], while. Derosa et al., Unal et al. and other researches demonstrated the relationship between MMP-9 and body weight parameters in patients with morbid obesity before bariatric surgery $[27,35,36]$ as well as after significant body weight reduction as a result of bariatric surgery [37-40]. However, no statistically significant correlation between MMP levels and body weight parameters was observed in this study. It is also worth mentioning that a statistically significant drop in MMP-9 levels was observed along with the reduction in body weight (8546.49; 2210.59-30522.40 ng/mL vs. 8024.56; 2210.59-46,160 ng/mL; $p=0.039)$.

In a study of 328 subjects (163 morbid obesity patients and 165 control group subjects), Derosa et al. observed that the activity of MMP-2 was significantly higher in morbid obesity patients, similar as in the case of MMP-9 [27]. The present study also demonstrated that the blood levels of MMP-2 in OB1 group was statistically significantly higher than in the OB2 group (46.19; 11.23-419.06 ng/mL vs. 39.26;
8.90-141.47 $\mathrm{ng} / \mathrm{mL} ; p=0.007)$ and in the control group. Therefore, it is worth underline lower probability of plaque destabilization, after surgery.

Unek et al. examined the relationship between hsCRP and $\mathrm{SCD} 40 \mathrm{~L}$ levels and the body weight in a group of 148 patients not suffering from type 2 diabetes. They observed higher hsCRP and sCD40L levels in obese patients as compared to overweight or normal weight patients while also demonstrating a positive correlation between hsCRP and $\mathrm{SCD} 40 \mathrm{~L}$ levels and BMI in the entire study population $(r=0.514, p=0.0001$ and $r=0.283$, $p=0.0001$, respectively). Guldiken et al. [22] were unable to demonstrate such correlation between sCD40L levels and the BMI as well as between the levels of hsCRP and sCD40L. In our study group, no statistically significant correlation was observed between the levels of sCD40L and hsCRP, as well as between changes of these levels in the follow-up period. However sCD40L levels currently observed in the OB1 group were similar to those observed by Schernthaner et al. in the group of patients with morbid obesity $(3.63 \pm 4.30$ vs. $3.7 \pm 1.5 \mathrm{ng} / \mathrm{mL})$ [41]. One should not overlook highlighting the observed strong correlation between sCD40L and PAI-1 $(r=0.53115$, $p=0.0005)$ as well as moderate correlation between $\triangle \mathrm{CD} 40 \mathrm{~L}$ and $\triangle \mathrm{PAI}-1 \quad(r=0.43109 ; p=0.0097)$ in the group of morbid obesity patients, which may contribute to less complications of atherosclerosis, by antypromoting thrombus formation in ruptured plaque. According to the available literature, no correlations between the tested parameters have been studied to date in morbid obesity patients. Hanusch-Enserer et al., who conducted a study in a similar group of patients, observed a statistically significant drop in PAI-1 levels upon follow-up; an insignificant drop was also observed in the study group in the present study [23].

In a study of 34 patients subjected to bariatric surgery, Hanusch-Enserer et al. observed a drop in CD62E (E-selectin) levels during a 6-month follow-up period [23]. In our study group, an insignificant drop in this parameter was observed $(56.48 ; 21.87-191.71 \mathrm{ng} / \mathrm{mL}$ vs. $54.05 ; 14.46-239.21 \mathrm{ng} / \mathrm{mL})$.

\section{Conclusions}

Assessment of laboratory markers of arterial remodeling and metabolism suggest their adverse changes in patients with morbid obesity, which potentially increase cardiovascular risk. However, body mass reduction due to bariatric surgery improves biochemical markers of arterial remodeling parameters as well as to beneficial changes in the metabolism. 
Conflict of Interest Justyna Domienik-Karłowicz: no conflict of interests

Zuzanna Rymarczyk: no conflict of interests

Olga Dzikowska-Diduch: no conflict of interests

Wojciech Lisik: no conflict of interests

Andrzej Chmura: no conflict of interests

Urszula Demkow: no conflict of interests

Piotr Pruszczyk: no conflict of interests

Open Access This article is distributed under the terms of the Creative Commons Attribution License which permits any use, distribution, and reproduction in any medium, provided the original author(s) and the source are credited.

\section{References}

1. Havel PJ. Update on adipocyte hormones. Diabetes. 2004;53 Suppl 1:S143-51. doi:10.2337/diabetes.53.2007.S143.

2. McGrath JC, Deighan C, Briones AM, et al. New aspects of vascular remodelling: the involvement of all vascular cell types. Exp Physiol. 2005;90(4):469-75. doi:10.1113/expphysiol.2005.030130. Epub 2005/05/17

3. Vinay Kumar RSC, Stanley L. Robbins. Patologia. 2005.

4. Galis ZS, Khatri JJ. Matrix metalloproteinases in vascular remodeling and atherogenesis. Circ Res. 2002;90(3):251-62.

5. Galis ZS, Sukhova GK, Lark MW, et al. Increased expression of matrix metalloproteinases and matrix degrading activity in vulnerable regions of human atherosclerotic plaques. J Clin Invest. 1994;94(6): 2493-503.

6. Bouloumie A, Sengenes C, Portolan G, et al. Adipocyte produces matrix metalloproteinases 2 and 9: involvement in adipose differentiation. Diabetes. 2001;50(9):2080-6.

7. Newby AC. Matrix metalloproteinases regulate migration, proliferation, and death of vascular smooth muscle cells by degrading matrix and non-matrix substrates. Cardiovasc Res. 2006;69(3):614-24.

8. Newby AC. Do metalloproteinases destabilize vulnerable atherosclerotic plaques? Curr Opin Lipidol. 2006;17(5):556-61.

9. Ouchi N, Kihara S, Arita Y, et al. Adipocyte-derived plasma protein, adiponectin, suppresses lipid accumulation and class A scavenger receptor expression in human monocyte-derived macrophages. Circulation. 2001;103(8):1057-63.

10. Ryan AS, Berman DM, Nicklas BJ, et al. Plasma adiponectin and leptin levels, body composition, and glucose utilization in adult women with wide ranges of age and obesity. Diabetes Care. 2003;26(8):2383-8

11. Owecki M, Miczke A, Pupek-Musialik D, et al. Circulating serum adiponectin concentrations do not differ between obese and nonobese caucasians and are unrelated to insulin sensitivity. Horm Metab Res Horm Stoffwechselforschung Horm Metab. 2007;39(1): 25-30.

12. Ryan AS, Nicklas BJ, Berman DM, et al. Adiponectin levels do not change with moderate dietary induced weight loss and exercise in obese postmenopausal women. Int J Obes Relat Metab Disord: J Int Assoc Study Obes. 2003;27(9):1066-71.

13. Abbasi F, Lamendola $\mathrm{C}$, McLaughlin $\mathrm{T}$, et al. Plasma adiponectin concentrations do not increase in association with moderate weight loss in insulin-resistant, obese women. Metab Clin Exp. 2004;53(3): 280-3.

14. Owecki M. Rozprawa habilitacyjna. Analiza stężeń adiponektyny w surowicy i ocena ich związku z wybranymi parametrami metabolizmu oraz badanie polimorfizmu genu adiponektyny $\mathrm{w}$ otyłości u ludzi: Katedra i Klinika Endokrynologii, Przemiany
Materii i Chorób Wewnętrznych Uniwersytetu Medycznego im. Karola Marcinkowskiego w Poznaniu; 2008.

15. Schondorf T, Maiworm A, Emmison N, et al. Biological background and role of adiponectin as marker for insulin resistance and cardiovascular risk. Clin Lab. 2005;51(9-10):489-94. Epub 2005/11/16.

16. Trujillo ME, Scherer PE. Adiponectin-journey from an adipocyte secretory protein to biomarker of the metabolic syndrome. J Intern Med. 2005;257(2):167-75. doi:10.1111/j.1365-2796.2004.01426.x. Epub 2005/01/20.

17. Unek IT, Bayraktar F, Solmaz D, et al. Enhanced levels of soluble CD40 ligand and C-reactive protein in a total of 312 patients with metabolic syndrome. Metabolism. 2010;59(3):305-13. doi:10.1016 j.metabol.2009.04.034. Epub 2009/12/17.

18. Huang Y, Qiu J, Zhang D, et al. Elevated soluble CD40 ligand in diabetic patients with painless myocardial infarction. Biofactors. 2011;37(2):88-94. doi:10.1002/biof.145. Epub 2011/04/14.

19. Lim HS, Blann AD, Lip GY. Soluble CD40 ligand, soluble Pselectin, interleukin-6, and tissue factor in diabetes mellitus: relationships to cardiovascular disease and risk factor intervention. Circulation. 2004;109(21):2524-8. doi:10.1161/01.CIR. 0000129773.70647.94. Epub 2004/05/12.

20. Palomo IG, Jaramillo JC, Alarcon ML, et al. Increased concentrations of soluble vascular cell adhesion molecule- 1 and soluble CD40L in subjects with metabolic syndrome. Mol Med Report. 2009;2(3):4815. doi:10.3892/mmr_00000125. Epub 2009/05/01.

21. Unek IT, Bayraktar F, Solmaz D, et al. The levels of soluble CD40 ligand and C-reactive protein in normal weight, overweight and obese people. Clin Med Res. 2010;8(2):89-95. doi:10.3121/cmr. 2010.889. Epub 2010/07/28.

22. Guldiken S, Demir M, Arikan E, et al. The levels of circulating markers of atherosclerosis and inflammation in subjects with different degrees of body mass index: soluble CD40 ligand and highsensitivity C-reactive protein. Thromb Res. 2007;119(1):79-84. doi:10.1016/j.thromres.2005.12.019. Epub 2006/02/16

23. Hanusch-Enserer U, Zorn G, Wojta J, et al. Non-conventional markers of atherosclerosis before and after gastric banding surgery. Eur Heart J. 2009;30(12):1516-24. doi:10.1093/eurheartj/ehp108. Epub 2009/04/22.

24. Primrose JN, Davies JA, Prentice CR, et al. Reduction in factor VII, fibrinogen and plasminogen activator inhibitor-1 activity after surgical treatment of morbid obesity. Thromb Haemost. 1992;68(4):3969. Epub 1992/10/05.

25. Diabetologiczne PT. Zalecenia kliniczne dotyczące postępowania u chorych na cukrzycę 2011. Diabetologia Praktyczna. 2011;12, Suplement A.

26. Fried M, Hainer V, Basdevant A, et al. Interdisciplinary European guidelines for surgery for severe (morbid) obesity. Obes Surg. 2007;17(2):260-70. Epub 2007/05/05.

27. Derosa G, Ferrari I, D’Angelo A, et al. Matrix metalloproteinase-2 and -9 levels in obese patients. Endothelium : J Endothelial Cell Res. 2008;15(4):219-24.

28. Cicero AF, Derosa G, Manca M, et al. Vascular remodeling and prothrombotic markers in subjects affected by familial combined hyperlipidemia and/or metabolic syndrome in primary prevention for cardiovascular disease. Endothelium : Journal Endothelial Cell Res. 2007;14(4-5):193-8.

29. Woelnerhanssen B, Peterli R, Steinert RE, Peters T, Borbely Y, Beglinger C. Effects of postbariatric surgery weight loss on adipokines and metabolic parameters: comparison of laparoscopic Roux-en-Y gastric bypass and laparoscopic sleeve gastrectomy-a prospective randomized trial. Surgery for obesity and related diseases: official journal of the American Society for Bariatric Surgery. 2011(Journal Article).

30. Chan JM, Rimm EB, Colditz GA, et al. Obesity, fat distribution, and weight gain as risk factors for clinical diabetes in men. Diabetes Care. 1994;17(9):961-9. Epub 1994/09/01. 
31. Colditz GA, Willett WC, Rotnitzky A, et al. Weight gain as a risk factor for clinical diabetes mellitus in women. Ann Intern Med. 1995;122(7):481-6. Epub 1995/04/01.

32. Promintzer-Schifferl M, Prager G, Anderwald C, et al. Effects of gastric bypass surgery on insulin resistance and insulin secretion in nondiabetic obese patients. Obesity (Silver Spring). 2011;19(7): 1420-6. doi:10.1038/oby.2011.92. Epub 2011/04/16.

33. Ouchi N, Kihara S, Funahashi T, et al. Reciprocal association of Creactive protein with adiponectin in blood stream and adipose tissue. Circulation. 2003;107(5):671-4. Epub 2003/02/13.

34. Kosmala W, Plaksej R, Przewlocka-Kosmala M, KuliczkowskaPlaksej J, Bednarek-Tupikowska G, Mazurek W. Matrix metalloproteinases 2 and 9 and their tissue inhibitors 1 and 2 in premenopausal obese women: relationship to cardiac function. International journal of obesity (2005). 2008;32(5):763-71.

35. Unal R, Yao-Borengasser A, Varma V, et al. Matrix metalloproteinase9 is increased in obese subjects and decreases in response to pioglitazone. J Clin Endocrinol Metab. 2010;95(6):2993-3001.

36. Catalan V, Gomez-Ambrosi J, Rodriguez A, et al. Increased adipose tissue expression of lipocalin-2 in obesity is related to inflammation and matrix metalloproteinase-2 and metalloproteinase- 9 activities in humans. J Mol Med (Berlin, Germany). 2009;87(8):803-13.

37. Hanusch-Enserer U, Zorn G, Wojta J, et al. Non-conventional markers of atherosclerosis before and after gastric banding surgery. Eur Heart J. 2009;30(12):1516-24.

38. Laimer M, Kaser S, Kranebitter M, et al. Effect of pronounced weight loss on the nontraditional cardiovascular risk marker matrix metalloproteinase-9 in middle-aged morbidly obese women. Int $\mathbf{J}$ Obes. 2005;29(5):498-501.

39. Sheu WH, Chang TM, Lee WJ, et al. Effect of weight loss on proinflammatory state of mononuclear cells in obese women. Obesity (Silver Spring). 2008;16(5):1033-8.

40. Madsen EL, Bruun JM, Skogstrand K, et al. Long-term weight loss decreases the nontraditional cardiovascular risk factors interleukin-18 and matrix metalloproteinase-9 in obese subjects. Metab Clin Exp. 2009;58(7):946-53.

41. Schernthaner GH, Kopp HP, Krzyzanowska K, et al. Soluble CD40L in patients with morbid obesity: significant reduction after bariatric surgery. Eur J Clin Invest. 2006;36(6):395-401. doi:10.1111/j.13652362.2006.01649.x. Epub 2006/05/11. 